me but I did not use it and I confined myself to the use of strychnine, morphine, and caffeine, the last both hypodermically and as strong coffee, and it is in a great measure, I think, to the last drug that the patient owes his recovery. Liverpool.

\section{SUCCESSFUL REVOVAL OF A VAGINAL TUMOUR DURING PREGNANCY.}

By L. O. Martin, M R.C.S. EnG., L.R.O.P.Lond.

ON Oct. 13th, 1903, I was called to see a patient alleged to be in premature labour. The presence of some hæmorrhage rather tban labour pains which, as a matter of fact, were absent, made her think that labour had begun. She stated that she was ab ut seven months pregnant. ' On examination I found a tumour of about the size of an orange protruding just outside the vagina and having the appearance of a polypus. On its lower and posterior aspect there was a slough about three-quarters of an inch in diameter; throughout the greater part of its extent it looked congested and felt somewhat hard. I had no difficulty in replacing it in the vagina, the manipulation, however, leading to some hæmorrhage. I then made a vaginal examination and ascertained that it was not connected in any way with the cervix or os uteri, both of which were perfectly free and normal, but that it was attached along the posterior wall of the vagina. It extended upwards for a couple of inches by a broad and shallow attachment, there being no pedicle. I advised its removal as soon as possible, as I had no doubt that it would prove a mechanical obstruction should labour occur prematurely. In addition to that the danger that might arise from its septic condition in these circumstances could not possibly be overlooked.

On Oct. 15th I operated under A C.E. mixture and removed the tumour. There was a considerable amount of bæmorrhage during the operation owing to the great vascularity of the tumour ; one large vein in particular gave some trouble and had to be ligatured. The oozing after removal was also troublesome and yielded to packing of the vagina with double cyanide gauze $\mathbf{s}$ aked in lukewarm carbolic lotion of strength 1 in 50 The subsequent progress of the case was entirely satinfactory and calls for no remarks. On the eleventh day after operation the patient was up. She was confined on Dec 2nd, labour being quite normal and the child healthy and well developed. The patient's previous history contains nothing of importance. I had attended her two years previously when I had to deliver her with forceps owing to a face presentation.

The following is the report of the Clinical Research Association on the histology of the tumour: "There is no evidence of malignancy in this specimen. It consists of fibro-muscular tissue permeated with very large veins, many of which are thromboser. The surface is ulcerated and inflamed. The e appearances suggest that the tumour was primarily a varix of the vaginal wall which has become polypoid and influmed."

I have connluered this case worth recording for the following reasons: (1) becanse of the occurrence and removal of the tumnur during pregnancy; (2) because of the fact that labour was not induced by the unavoidable and frequent manipulation which the operation and subsequent dressing involved; and ( 3 ) because of the rather unusual site of the tumour.

Woolston, Southampton.

Central Mrdwives Board. - At the last meeting of the Central M dwives Board, upon c nsideration of applications for certiticates the names of 270 women were pas:ed under Section 2 of the Act and ordered for entry on the roll. Of this total 65 claimed as holding the certificate of the Obstetrical Society of London, five that of the Rotunda Hospital, Dublin, on that of the Coombe Lying-in Hospital, Dublin, one that of the Liverpool Lying-in Hospital, eipht that of St. Mary's Ho-pital. Manchester, two that of the Salvation Arniy Miternity Home, and 188 were admitted as having been in bonâa-fide practice for one year prior to July 31 st, 1902.

\section{d efthrtrot}

\section{HOSPITAL PRACTICE, BRITISH AND FOREIGN.}

Wulla autem est alia pro certo noscendi via, nisi quamplurimas er morborum et dissectionum historias, tum aliorum tum proprias sollectas habere, et inter se comparare.-MongaGrI De Sed. et Carts. rorb., lib. iv., Procmium.

\section{ST. GEORGE'S HOSPITAL.}

CONSERVATIVE OPERATION IN A CASE OF ACUTE SUPPURATIVE SALPINGITIS.

(Under the care of Mr. Herbert W. Allingham.)

For the notes of the case we are indebted to $\mathbf{M r}$. $\mathbf{T}$. Crisp English, surgical registrar.

The patient, a female, aged 17 years, was admitted into St. George's Hospital on Oct. 20th, 1903. Five days previously she had been seized with abdominal pain referred at first to the umbilical region and later to the right iliac fossa. Vomiting occurred at the onset of the pain and twice on the following day. The pain became more severe in spite of rest in bed; the bowels acted once during the week before admission, no purgatives or enemata being used. Micturition had been painful and the vaginal discharge, which had existed for several months, had become more profuse. There was no history of a similar attack previously and in other respects she had always been healthy; menstruation had been regular, the last flow occurring a fortnight before the commencement of the attack.

On admission the patient was anæmic but fairly nourished. The temperature was $1014^{\circ} \mathrm{F}$., the pulse was 130 , and the tongue was dry and furred. Pain was complained of over the entire abdomen but mostly in the right iliac fossa and the knees were drawn up. The abdominal wall moved but slightly with respiration; there were great tenderness and rigidity in the lower part of the abdomen, most marked on the right side; no swelling could be felt and there was no distension or abnormal dulness. A diagnosis of appendicitis or mischief in the right side of the pelvis was made.

Operation was performed by Mr. Allingham about one hour after admission. The abdomen was opened by an oblique incision over the right iliac fossa but the appendix was found to be bealthy ; further examination showed that the trouble was in the pelvis. The incision was therefore prolonged downwards. The right Fallopian tube was swollen and injected; on pressure a quantity of pus oozed from its fimbriated extremity which was patent. A similar condition was found on the left side but a larger quantity of pus was present; the uterus and ovaries were normal. The case seemed particularly suitable for conservative treatment, as the pelvic peritoneum was only slightly involved and there was complete absence of adhesions. The pus was therefore thoroughly pressed out of the tubes, the surrounding parts were carefully cleansed with sponges and a large strip of iodoform gauze was passed from the lower angle of the wound into Douglas's pouch, and the upper part of the wound was sutured in the ordinary way. No pain, vomiting, or distension followed the operation. The bowels were opened on the following mornivg by a turpentine enema and flatus passed freely through a r+ctal tube. The temperature kecame normal on the third day. The gauze plug was removed three days later and a tube was inserted in its place ; this was finally removed on the twelfth day. During the third week the patient had a slight rise of temperature with pain in the left hypochondriac regions but no local signs either in the thorax or abdomen were found to account for this. The symptoms were relieved by antipyrin and bismuth. She got up at the end of the fourth week, the wound being sountly healed, and was sent to the convalescent home on the thirty. fitth day after operation.

Remarks by Mr. CRISP ENGLISH - Only within recent years have conservative operations upon the uterine appendages been advocated and carried into practice. The value of conservative treatment, however, is not yet generally recognised and many still consider that removal of the tube and ovary en masse is the necessary treatment for disease of either of these structures. One of the first principles of surgery is to remove as little as is consistent with the safety and welfare 